\title{
EDUCATIONAL VALUES FOR STUDENT CHARACTER BUILDING (A HERMENEUTIC ANALYSIS)
}

\author{
Oleh: Desyandri \\ E-mail. desyandri@yahoo.co.id \\ FIP Universitas Negeri Padang
}

\begin{abstract}
This article aims to discover, interpret, and identify the educational values embodied in the song of Minangkabau creation by NN. The identification process is done by a multidisciplinary hermeneutic analysis. Interpretation is generated by associating the aspects of language, music/songs, psychological, socio-cultural, and educational, so it can be identified seven (7) educational values. The educational values is a means to educate learners to perform the actions and behaviors that reflect proper Minang people. Education and learning as a means of cultural inheritance are obliged to explore, socialize, actualize, and cultivate the educational values on an ongoing basis in order to create learners who are well-mannered, civilized and noble character.
\end{abstract}

Keywords: custom, Minangkabau, songs, education, character, hermeneutic

\section{PENDAHULUAN}

Adat Minangkabau dirancang berdasarkan akal-budi (perpaduan antara pikiran dan perasaan untuk menimbang baik dan buruk mengacu pada alam takambang jadi guru, raso jo pareso (rasa/karsa dengan periksa/kontrol) yang menurut alua jo patuik (alur dan patut) akan melahirkan tindakan (sikap dan perilaku) yang baik dengan mempertimbangkan perasaan malu dan sopan, agar memunculkan kearifan pengetahuan dan berperilaku sebagai manusia dalam kehidupan sosial yang beradab (Zainuddin, 2010:106). Adat Minangkabau memberikan pedoman nilai-nilai yang bersumberkan dari akal-budi, sehingga melahirkan tindakan dan perilaku masyarakat yang mencerminkan karakter khas orang Minangkabau.

Pewarisan nilai-nilai adat Minang telah dilakukan secara turun-temurun dengan berbagai cara. Salah satu cara yang digunakan adalah melalui seni pertunjukan atau kesenian Minang, seperti yang dikemukakan Amir (2011:76) bahwa "adat-istiadat merupakan aneka kelaziman dalam suatu nagari. Kelaziman ini pada umumnya menyangkut pengejawantahan unjuk rasa seni budaya masyarakat, seperti acara-acara keramaian anak nagari (generasi muda), seperti pertunjukan randai, saluang, aneka tari-tarian, dan aneka ragam kesenian. Amir menambahkan, bahwa kebanyakan adat atau nilai-nilai sopan-santun, basa-basi, serta tata krama pergaulan termasuk dalam klasifikasi "adat-istiadat".

Salah satu jenis kesenian yang ada di Minangkabau adalah lagu Minang. Lagu Minang, khususnya lagu Minang lamomerupakan ungkapan perasaan dan pemikiran seniman Minang yang dituangkan ke dalam bentuk musik dan lagu yang mengandung nilai-nilai dan menggambarkan kondisi realitas yang terjadi di masyarakat, serta proses aktualisasi nilai-nilai yang terkandung dalam adat Minangkabau. Nilai-nilai tersebut dijadikan sebagai pedoman dalam melahirkan tindakan dan perilaku yang mencerminkan karakter orang Minang. Barendregt (2002:416) mengatakan bahwa:

Minang songs, provides one of the avenues through which identification as Minangkabau is experienced, defined, and consumed internally. It constructs a Minangkabau sensibility "by depicting a recognizable landscape through the use of metaphors" related to migration and the homeland.

Lagu Minang mengidentifikasikan adat budaya Minang kabau yang dianut, didefinisikan, dan dikonsumsi secara internal serta dapat 
membangun perasaan tentang keindahan alam yang dapat dikenali melalui penggunaan metaforaterkait dengan ranah Minang dan kebiasaan atau tradisi merantau. "The attachment goes beyond this landscape to "a community sharing the same moral values" (ibid.:417). Lagu-lagu Minang lebih dari sekedarmenceritakan tentang kerinduan terhadap alam Minangkabau, bahkan merupakan upaya masyarakat untuk berbaginilai-nilaimoral.

Merriam (1964:201) mengemukakan bahwa:

Song texts, then, can be used as a means of action directed toward the solution of problems which plague a community. While this can take the form of ridicule and shame, or sanctioned legal action, it is also apparent that song texts provide psychological release for the participants. Indeed, because of the freedom of expression allowed in song, texts seem clearly to provide an excellent means for the investigation of the psychological processes of the people who constitute a culture.

Lirik lagu dapat digunakan sebagai sarana mengarahkan tindakan menuju pada solusi terhadap permasalahan yang mengganggu masyarakat. Meskipun hal ini dapat berbentuk ejekan dan perasaan malu, atau tindakan sanksi hukum, dan teks-teks lagu memberikan rilispsikologis. Kebebasan berekspresi diperbolehkan dalam lagu, lirik sebagai sarana yang sangat baik untuk penyelidikan terhadap proses psikologis individu dan masyarakat dalam suatu budaya.

Hal tersebut senada dengan pendapat Hajizar (2012) yang menyatakan bahwa lagu-lagu Minang berangkat dari presepsi nilai-nilai sosial masyarakat. Dengan demikian, lagu-lagu Minang dapat digambarkan sebagai sebuah keintiman atau kedekatan dengan budaya Minangkabau, seperti yang dikemukakan Fraser (2011), "Minang songs is a form of cultural intimacy, one that allows the Minangkabau to recognize themselves within the nation as distinct from its other constituents".

Nilai-nilai tersebut sangat penting diaktualisasikan dalam proses pendidikan dan pembelajaran di sekolah menuju pembangunan karakter peserta didik. Pendidikan sebagai proses pembudayaan bukan hanya merupakan proses transformasi pengetahuan yang terfokus pada penguasaan kemampuan intelektual semata, tetapi juga berperan mewariskan nilai-nilai positif budaya dan kearifan lokal sebagai tuntunan dalam melahirkan tindakan dan perilaku. Dengan kata lain, pendidikan seharusnya berupaya menjadikan nilai-nilai edukatif adat Minangkabau dan lagulagu Minang sebagai pedoman untuk melahirkan tindakan dan perilaku peserta didik. Upaya pembudayaan tersebut dapat dijadikan sebagai sarana untuk menumbuhkan dan membangun karakter peserta didik.

Muhadjir (2003: 20) mengemukakan tiga fungsi pendidikan, yaitu: (1) menumbuhkan kreativitas peserta didik; (2) memperkaya khasanah budaya manusia, memperkaya isi nilai-nilai insani dan nilai-nilai Ilahi; dan (3) menyiapkan tenaga kerja produktif. Pandangan-pandangan tentang pendidikan yang telah dikemukakan tersebut dapat diambil sebuah benang merah bahwa pendidikan merupakan upaya pemberdayaan dengan menumbuhkan kreativitas peserta didik agar menjadi manusia yang kaya dengan nilai-nilai insani dan Ilahi, serta berbudaya.

Ditinjau dari tujuan pendidikan, Tilaar (2010: 20-21) mengemukakan bahwa tujuan pendidikan bukan hanya manusia yang terpelajar tetapi manusia yang berbudaya, sehingga pendidikan dapat berfungsi sebagai proses pemberdayaan dan proses pembudayaan. Pendidikan sebagai proses pemberdayaan dan pembudayaan mengisyaratkan bahwa pendidikan memiliki tugas menumbuhkembangkan nilai-nilai positif yang terkandung dalam sebuah kebudayaan. Di pihak lain, Muhadjir (2003: 97) mengemukakan pendidikan adalah upaya normatif untuk mencapai sesuatu tujuan. Tujuan pendidikan adalah terjadinya tingkat perkembangan normatif yang lebih baik pada peserta didik. Dengan kata lain, pendidikan dimaksudkan untuk menumbuhkembangkan sikap dalam rangka membangun karakter peserta didik yang membawa 
pewarisan nilai-nilai positif serta pembentukan sikap dan kesadaran untuk masa depan budaya yang lebih baik.

Realita yang terjadi di lapangan terlihat bahwa proses pendidikan belum optimal dan lebih berorientasi pada penguasaan kemampuan intelektual semata, mengabaikan prosespelestarian dan aktualisasi nilai-nilai adat Minangkabau dan nilai-nilai edukatif yang terkandung dalam lagulagu Minang, sehingga pendidikan hanya dijadikan sebagai alat untuk memperkaya pengetahuan tetapi miskin nilai-nilai. Tilaar (2010: 218) mengemukakan bahwa intelektualisme yang telah menjadi ciri pendidikan nasional telah mengasingkan budaya dan apresiasi budaya dalam pendidikan nasional. Bukan berarti bahwa kognisi tidak diperlukan dalam pengembangan kepribadian manusia.

Pandangan Tilaar terlihat dalam realita pembelajaran pendidikan seni musik di sekolahsekolah. Pembelajaran didominasi fungsi hiburan semata, pemberian materi dalam bentuk hafalan musik/lagu-lagu Minang, mengekplorasi kandungan nilai-nilai edukatif secara garis besar tanpa dilanjutkan dengan pengimplementasian dan pembudayaan nilai-nilai tersebut dalam kehidupan sehari-hari peserta didik. Di sisi lain, sekolah terlihat mulai meninggalkan lagu Minang, sehingga nilai-nilai edukatif yang terkandung dalam lagulagu tersebut tidak lagi difungsikan sebagaimana mestinya. Hal ini dapat dibuktikan dengan sedikitnya lagu Minang yang dibelajarkan di sekolah dan kebanyakan peserta didik kurang mengetahui lagu Minang salah satunya adalah lagu Minangkabau.

Seharusnya pendidikan seni musik dapat mengembangkan rasa keindahan, kreativitas, dan kepribadian, serta menjadikan peserta didik lebih produktif dan berbudaya (Astuti: 2010: 5). Pembelajaran tentang lagu Minangkabau dapat mengedukasi peserta didik untuk mengetahui kekhasan dan rasa cinta terhadap ranah Minang.

Permasalahan ini dapat menyebabkan munculnya kecenderungan perilaku dan karakter peserta didik yang tidak beradat/tidak beradab, seperti: kurangnya rasa menghargai dan menghormati orang lain, kurangnya sopan-santun, lebih mementingkan diri sendiri, serta kurang peduli dengan adat atau budaya daerah mereka sendiri. Perilaku negatif ini, jika dibiarkan terusmenerus mengakibatkan tercerabutnya peserta didik dari budayanya sendiri.Orang Minang yang tidak tahu dengan adat Minangkabau. Seperti kata pepatah Minang, "Lah lupo kacang jo kuliknyo", maksud pepatah ini menggambarkan seseorang yang telah lupa dengan adat budayanya sendiri.

Permasalahan memudarnya nilai-nilai adat Minangkabau dan mengingat pentingnya nilai-nilai edukatif yang terkandung dalam lagu Minang sebagai sarana untuk membendung perilaku peserta didik yang mengarah pada hal-hal negatif dan sekaligus sebagai upaya membangun karakter peserta seharusnya mendapat perhatian yang serius, salah satunya dengan melakukan kajian dan penelitian mendalam tentang nilai-nilai edukatif lagu Minang, diantaranya lagu Minangkabauciptaan NN (No Name).

\section{METODE PENELITIAN}

Metode penelitian untuk mengungkapkan, menginterpretasikan, dan mengidentifikasikan nilai-nilai edukatif lagu Minangkabau menggunakan metode penelitian filsafat, yakni metode hermeneutik yang mengacu pada unsurunsurdan penerapan analisis hermeneutiksecara multidisipliner.Fithri (2013: 64-74) mengutip pendapat Ricoeur yang mengemukakan bahwa unsur-unsur dan penerapan teori hermeneutik, yaitu1) objektivikasi struktur teks: hermeneutik tidak mencari kesamaan maksud dengan pengarang teks, tetapi menafsirkan makna teks secara objektif sesuai dengan yang diisyaratkan teks, 2) distansiasi (perjarakan): jalan utama menuju otonomi teks, 3) apropriasi: menjadikan sesuatu yang sebelumnya "asing" kemudian menjadi "milik sendiri" dan bertujuan untuk mengaktualkan makna teks bagi pembaca terkini dan 4) analogi permainan: teks menjadi lebih lentur dan memungkinkan kreativitas penafsir untuk menemukan makna-makna baru. Analogi permainan dilakukan dengan mengaitkan 
proses interpretasi pada aspek multidisipliner, yaitu aspek kebahasaan, musik/lagu, psikologi, sosiokultural, dan pendidikan.

\section{HASIL DAN PEMBAHASAN}

Lagu Minangkabau merupakan lagu Minang klasik dan tidak diketahui penciptanya atau NN (No Name). Lagu Minangkabau dipopulerkan pertama kali oleh Lily Syarif pada tahun 1960-an. Berikut ini dipaparkan hasil analisis hermeneutik terhadap lirik dan musik lagu Minangkabau.

1. Aspek Kebahasaan

\section{a. Bait Pertama}

Kalimat pertama lirik lagu Minangkabau, menyatakan bahwa Minangkabau tanah nan den cinto. Secara leksikal atau dalam arti kamus dapat diterjemahkan bahwa kata "Minangkabau" merupakan sebuah tempat atau lokasi yang menggunakan aturan dan tatanan adat budaya di Minang. Arti kata "tanah" dapat diterjemahkan sebagai sebuah kampung halaman atau ranah, tempat tinggal, tempat seseorang (orang Minang) lahir, tumbuh, dan berkembang. Kata "den" dapat diterjemahkan sebagai sebutan diri sendiri bagi orang Minang. Sedangkan kata "cinto" berkaitan erat dengan unsur psikologis dan dapat diterjemahkan sebagai ungkapan perasaan suka, senang, rindu, dan cinta. Secara keseluruhan kalimat pertama lagu Minangkabau dapat diterjemahkan bahwa Minangkabau merupakan kampung halaman yang sangat dicintai oleh orang Minangkabau.

Kalimat pertama dapat ditafsirkan bahwa setiap orang Minangkabau sangat mencintai kampung halamannya.

Kalimat lagu kedua menyatakan bahwa pusako bundo dahulunyo". Kalimat kedua terdiri dari tiga kata, yakni pusako, bundo, dan dahulunyo. Kata "pusako" dapat diartikan sebagai sebuah warisan secara turun temurun. Kata bundomemiliki banyak arti, yakni: 1) ibu pertiwi atau tanah kelahiran, dan 2) panggilan khusus untuk orang tua perempuan (ibu), selain itu kata bundo memiliki arti yang sangat berpengaruh di Minangkabau, karena melambangkan bahwa garis keturunan atau warisan turun-temurun yang berlaku di Minangkabau didasarkan pada garis keturunan ibu. Kata dahulunyo menyangkut tentang ukuran waktu yang sudah berlangsung lama atau dengan kata lain sudah ada dari zaman nenek moyang.

Kalimat kedua dapat ditafsirkan bahwa Minangkabau sebagai sebuah aturan atau norma adat dan juga sebagai tanah tempat lahir, tumbuh, dan berkembangnya orang Minang merupakan warisan yang diturunkan melalui garis keturunan ibu (matrilineal) yang sudah ada semenjak zaman nenek moyang.

Kalimat ketiga lirik lagu Minangkabau menyatakan bahwa: rumah gadang nan sambilan ruang. Kalimat ketiga secara garis besar terdiri dari dua kelompok kata, yakni: rumah gadang dan sembilan ruang. Kelompok kata "rumah gadang" dapat diartikan sebagai sebuah rumah khas atau rumah adat orang Minangkabau. Rumah gadang yang luas dan memiliki sembilan ruang.

Kalimat keempat dalam bait pertama lirik lagu Minangkabau menyatakan bahwa: rangkiang baririk di halamannyo. Kalimat keempat terdiri dari tiga kata, yakni rangkiang, baririk, dan kata di halamannyo. Kata rangkiang dapat diartikan sebagai lumbung padi. Orang Minangkabau memiliki kebiasaan menyediakan sebuah tempat untuk menyimpan dan mengamankan hasil panen padi mereka. Kata baririk di halamannyo dapat diartikan bahwa di setiap rumah gadang memiliki beberapa tempat penyimpanan atau lumbung padi sebagai bekal bagi warga yang mendiami rumah gadang.

Kalimat keempat dapat ditafsirkan bahwa selain tinggal di rumah gadang, orang Minang memiliki kebiasaan untuk menabung atau menyimpan hasil panen padi atau dengan kata lain lumbung dapat difungsikan sebagai tempat persediaan makanan bagi penghuni rumah gadang dan keperluan makanan untuk pesta 
adat. Hasil panen yang terdapat dalam lumbung tersebut dapat digunakan sewaktu-waktu.

Keseluruhan lirik lagu Minangkabau, dapat ditafsirkan bahwa Minangkabau, baik sebagai sebuah tatanan adat maupun tempat lahir, tumbuh, dan berkembangnya orang Minang merupakan: 1) kampung halaman yang sangat dicintai baik bagi orang Minang yang berada di ranah Minang, maupun orang Minang yang berada di perantauan, 2) warisan seorang bundo (ibu) dari zaman nenek moyang dahulunya, 3) rumah tempat tinggal yang khas dan dikenal dengan nama rumah gadang yang memiliki sembilan ruang, dan 4) tempat persediaan makanan untuk keperluan makanan pengisi rumah gadang dan untuk keperluan upacara adat.

b. Bait Kedua

Bait kedua lirik lagu "Minangkabau", yakni "Jikok den kana hati den taibo, tabayangbayang di ruang mato". Kalimat tersebut dapat diartikan bahwa, jika perantau Minang mengenang atau mengingat kampung halaman dan Rumah Gadang, menjadikan hati mereka hiba. Suasana hati hiba ini disebabkan karena perantau berada jauh di negeri orang dengan semua permasalahan dan tantangan hidup yang dilaluinya.

Kecintaan dan kerinduan terhadap kampung halaman, yakni ranah Minangkabau berdampak pada kondisi imajinasi orang-orang atau masyarakat Minangkabau. Kampung halaman seakan-akan hadir di pelupuk mata mereka (tabayang-bayang di ruang mato).

2. Aspek Musik

\section{a. Unsur melodi}

Jarak nada (interval) yang terdapat dalam perjalanan melodi lagu Minangkabau terdiri dari 1) interval prime (berjarak nol nada/sama) sebanyak 8 buah, 2) interval seconde (berjarak $1 / 2$ atau 1 nada) sebanyak 42 buah, 3) interval ters (berjarak $1 \frac{1}{2}$ atau 2 nada) sebanyak 18 buah, dan 4) interval kwart (berjarak $2 \frac{1}{2}$ nada) sebanyak 2 buah. Jarak nada (interval) yang terdapat pada perjalanan melodi lagu
Minangkabau dapat dilihat pada tabel di bawah ini:

$\begin{array}{ccc}\begin{array}{c}\text { Tabel 1. Interval Lagu Minangkabau } \\ \text { Bnterval } \\ \text { Birama }\end{array} & \begin{array}{c}\text { Jumlah } \\ \text { Prime }\end{array} & 1,15,17,17,23,25,25, \quad 8 \text { buah } \\ \text { Seconde } & 31 & \\ & 01,02,04,05,05,05, \quad 42 \text { buah } \\ & 05,06,07,07,09,10, \\ & 12,13,13,13,13,14, \\ & 15,15,16,19,19,20 \\ & 21,21,21,21,22,23, \\ & 23,24,27,27,28,29, \\ & 29,29,29,30,31,31, \\ \text { Ters } & 32 & \\ & 01,03,03,03,03,09, \quad 18 \text { buah } \\ \text { Kwart } & 11,11,11,11,17,18, \\ & 19,19,25,26,27,27 \\ & 01,09 & 2 \text { buah }\end{array}$

Sumber: Pengolahan Data Penelitian

Berasarkan paparan jarak nada (interval) dalam gerakan melodi lagu Minangkabau di atas, dapat dikemukakan bahwa perjalanan melodi tersebut didominanasi oleh penggunaan interval seconde. Penggunaan interval seconde dalam melodi sebuah lagu dapat digolongkan pada gerak melodi melangkah. Gerak melodi melangkah merupakan pergerakan dari satu nada ke nada lain, baik bergerak ke nada yang lebih rendah atau ke nada lebih tinggi. Gerak melangkah ke nada yang lebih rendah dikenal dengan sebutan gerak melangkah turun, dan sebaliknya gerak melodi melangkah ke nada yang lebih tinggi dikenal dengan sebutan gerak melodi melangkah naik.

Gerak melangkah dalam perjalanan melodi lagu Minangkabau dapat dilihat dari potongan notasi melodi pada birama 5 sampai dengan birama 8, birama 13 sampai dengan birama 16, birama 21 sampai dengan birama 24 , birama 29 sampai dengan birama 32. Potonganpotongan melodi tersebut memiliki nada-nada yang sama, seperti yang terlihat pada gambar di bawah ini:

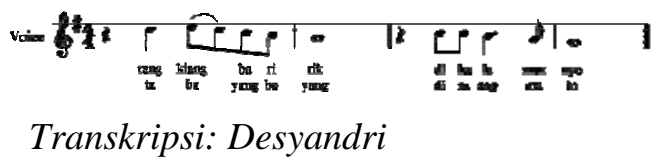

Notasi 1

Gerak Melangkah 
Gerak melangkah tersebut merupakan salah satu karakteristik lagu Minangkabau, di samping itu terdapat gerak melodi khas yang dikenal dengan sebutan galitiak/garinyiak atau cengkok Minang. Galitiak/garinyiak atau cengkok Minang secara jelas dapat diidentifikasi pada saat seseorang menyanyikan atau memainkan melodi lagu dan juga dapat diidentifikasi melalui gerakan nada-nada atau potongan melodi yang terdapat pada partitur lagu.

Galitiak/garinyiak atau cengkok Minang tersebut dapat dilihat pada potongan melodi, seperti gambar di bawah ini:

1) Birama 5 sampai dengan 8 atau birama 21 samai dengan 24 , seperti gambar berikut:

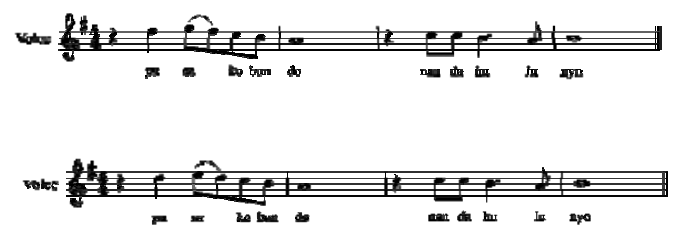

Transkripsi: Desyandri

\section{Notasi 2}

\section{Galitiak (cengkok) Minang}

2) Birama 13 sampai dengan 16 atau birama 29 sampai dengan 32, seperti gambar berikut:

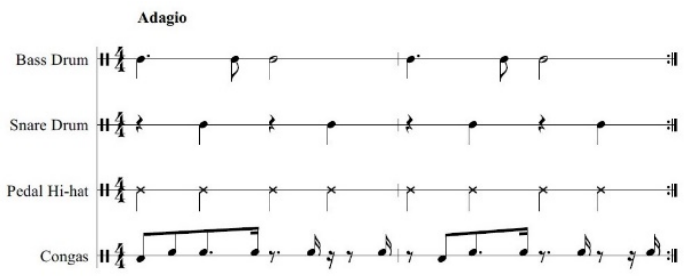

Transkripsi: Desyandri

Notasi 3

\section{Galitiak (cengkok) Minang (frase konsekuen)}

Galitiak atau cengkok yang terdapat pada gerakan melodi lagu Minangkabau merupakan faktor penentu yang membedakan kekhasan lagu-lagu Minang dibanding lagu-lagu daerah lain yang ada di Indonesia dan sekaligus memberikan sentuhan dan nuansa khusus pada semua masyarakat atau para perantau Minangkabau. Apabila masyarakat dan perantau Minangkabau mendengar gerakan melodi atau galitiak Minang tersebut, tak ayal ingatan mereka langsung tertuju pada suasana di kampung halaman atau ranah Minangkabau, apalagi melodi tersebut berasal dari bunyi alat musik tradisional minangkabau, seperti bansi, saluang, talempong, dan rabab.

Gerak melodi melangkah turun yang menjadi kekhasan Minang menggambarkan suasana yang cenderung tenang, aman, tentram, damai, harmonis atau dengan kata lain pergerakan melodi lagu Minangkabau dapat ditafsirkan sebagai gambaran suasana alam Minangkabau yang diliputi oleh suasana ketenangan, keamanan, ketenteraman, kedamaian, dan keharmonisan. Hal ini semakin meningkatkan rasa cinta dan rindu masyarakat atau para perantau Minang terhadap kampung halaman.

\section{b. Unsur Ekspresi}

Berdasarkan analisa dari berbagai macam versi mulai dari versi awal pada tahun 1960-an yang dipolpulerkan oleh Elly Kasim, tahun 1970-an yang dipopulerkan oleh Edy Silitonga, dan tahun 1970-1980an yang dipopulerkan oleh Betharia Sonata hingga versi sekarang terhadap lagu Minangkabau yang beredar di masyarakat menggambarkan bahwa kesemua versi lagu Minangkabau menggunakan pola irama yang beragam mengikuti tren irama pada zamannya, tetapi tetap mempertahankan kekhasan pola irama Minang. Kecenderungan penggunaan pola irama mengarah ke bentuk perpaduan pola irama Minang dengan modern. Pola irama tersebut dapat dilihat pada gambar berikut ini:

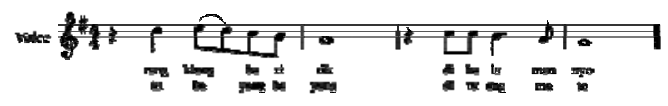

Transkripsi: Desyandri

Notasi 4

Pola Irama Khas Minangkabau (Lambat) 
Pola irama tersebut hampir mewarnai kekhasan musik Minang secara umum, terutama lagu-lagu Minang yang menggunakan tempo lambat dan sedang. Pola irama lagu Minangkabau tergolong ke dalam irama yang melankolis (lagu-lagu yang menggambar suasana sedih, mendayu-dayu (ratok), sehingga menggugah perasaan dan suasana hati masyarakat Minangkabau yang dilanda perasaan cinta dan rindu terhadap kampung halaman.

Perasaan cinta dan rindu masyarakat Minangkabau dan para perantau semakin menjadi-jadi jika lagu tersebut dimainkan dengan menggunakan atau memperdengarkan alat musik tradisional Minangkabau, seperti saluang(alat musik tiup yang terbuat dari bambu), bansi(alat musik tiup yang terbuat dari bambu dan mirip alat musik recorder), talempong(alat musik pukul yang terbuat dari logam), rabab(alat musik gesek yang dimainkan sambil duduk), dan gandang(gendang).

Kondisi kecintaan dan kerinduan tersebut membuat perasaan para perantau atau pendengar lagu Minangkabau semakin hiba dan sedih. Kehibaan atau kesedihan tersebut tidak pelak memunculkan tindakan dan perilaku, seperti: 1) segera pulang ke kampung halaman tercinta, 2) berupaya mengobati kecintaan dan kerinduan dengan bersilaturahmi sesama perantau yang tidak bisa pulang kampung, dan 3) menenggelamkan diri bersama alunan lagulagu Minang di negeri orang.

Bunyi alat-alat musik tradisional Minangkabau tersebut mampu menghipnotis dan membuai (meninabobokkan) pikiran dan perasaan masyarakat Minangkabau untuk selalu mengingat keindahan dan keelokan kampung halaman, ranah Minang. Suasana tersebut menjadi nilai-nilai yang berpengaruh kuat bagi masyarakat atau perantau Minangkabau, di samping sebagai alunan musik yang menghimbau atau memanggil perantau untuk pulang kampung, sekaligus sebagai penawar dan pengobat rasa rindu mereka di negeri orang.

Penggunaan pola irama khas Minangkabau, perjalanan melodi yang melankolis dengan nuansa yang sedikit maratok (sedih dan pilu), dinyanyikan dalam tempo (kecepatan lambat) yang seakan-akan maimbauimbau (memanggil-manggil), dan menghadirkan bunyi-bunyian yang bersumber dari alat-alat musik tradisional Minangkabau mengekspresikan betapa indahnya suasana ranah Minang. Kondisi ini menambah semakin tingginya kecintaan dan kerinduan pendengar dan para perantau terhadap kampung halaman, yakni ranah Minangkabau tacinto.

Selain pola irama khas Minang dan tempo lagu, elemen berikutnya adalah jangkauan nada (ambitus). Ambitus lagu Minangkabau berkisar antara nada D (5,) sampai dengan nada G' (1'), seperti yang terlihat pada gambar di bawah ini:

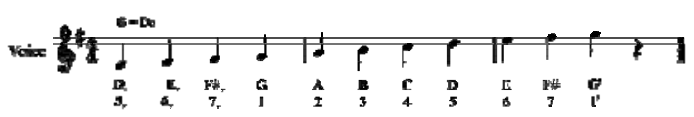

Transkripsi: Desyandri

\section{Notasi 5}

\section{Ambitus Lagu Minangkabau}

Ambitus lagu Minangkabau berjarak 1 $1 / 2$ oktaf (sebelas nada) dan tergolong pada jangkauan nada yang pendek dan tidak terlalu susah untuk dinyanyikan, serta sangat berpengaruh terhadap ekspresi seseorang ketika menyanyikan lagu. Jangakauan nada tersebut menggambarkan bahwa lagu Minangkabau merupakan lagu sederhana yang mudah diingat atau dihafalkan, sehingga memudahkan seseorang dalam proses pengekspresiannya. Hal ini sangat berkaitan dengan faktor kebertahanan dan kepopuleran lagu Minangkabau sampai dewasa ini.

Kebertahanan dan kepopuleran lagu Minangkabau hingga dewasa ini menandakan bahwa lagu tersebut disukai dan diminati oleh para pendengar, nasehat dan pesan yang disampaikan berupa nilai-nilai kecintaan dan kerinduan terhadap ranah Minang semestinya masih dijadikan sebagai pedoman bagi masyarakat Minangkabau dalam menjaga dan melahirkan tindakan dan perilaku atau sikap yang sesuai menurut norma atau aturan adat budaya Minangkabau.

3. Aspek Psikologi 
Ditinjau dari aspek psikologi, lirik dan musik lagu Minangkabaumenggambarkan bahwa secara kejiwaan orang-orang atau masyarakat dan perantau Minang memiliki hubungan timbal-balik yang sangat erat, baik terhadap suasana alam Minangkabau dan suasana rumah gadangnya maupun suasana kehidupan orang-orang atau masyarakat Minang ketika berada di ranah bundo, apalagi jauh di negeri orang (di luar Minangkabau).

Kondisi tersebutmenggugah suasana kejiwaan dan pemikiran mereka, dan akhirnya memengaruhi tindakan dan perilkau yang memunculkan rasa hiba yang mendalam dan kerinduan yang tinggi untuk segera pulang ke kampung halaman. Bagi orang-orang atau masyarakat Minangkabau yang belum bisa pulang dikarenakan berbagai alasan yang rumit, melampiaskan kehibaan dan kerinduan terahadap suasana kampuang halaman, bundo kanduang, dan rumah gadang dengan mendengarkan dan melihat rekaman Video Compact Disk (VCD) lagu-lagu Minang.

Secara garis besar, aspek psikologi (kejiwaan) masyarakat dan para perantau Minang terbentuk dari pengaruh hubungan sosiokultural masyarakat dan para perantau Minang, sehingga hubungan tersebut melahirkan perasaan hiba atau sedih dan selalu dipangil-panggil oleh ranah Minang tercinta.

4. Aspek Sosiokultural

Secara sosial, lagu Minangkabau menggambarkan kondisi ikatan yang kuat dalam payung sistem kekerabatan matrilineal. Hal ini memberikan kontribusi untuk mementingkan tanah kelahiran yang merupakan warisan atau pusaka bundo yang tetap terjaga dari zaman dahulu sampai sekarang, sehingga mereka selalu menghormati ibu (bundo) dengan cara mengenang dan mengingat-ingat ranah Minang dan suasana kehidupan di kampung halaman.

Hubungan kekerabatan sosial tersebut menjadi tali perekat antara perantau dengan masyarakat atau orang-orang yang berada di kampung halaman, terutama hubungan yang erat dengan sosok seorang ibu (bundo). Perantau yang tidak bisa pulang ke kampung halaman tidak tinggal diam, pada zaman sekarang mereka berinteraksi dengan menggunakan kecanggihan teknologi dan informasi.

Hubungan dan interaksi sosial tersebut merupakan sarana ampuh untuk mendekatkan hubungan antara perantau-perantau dengan keluarga dan masyarakat terdekat di kampuang halaman, selain itu ada beberapa kegiatan lain yang dilakukan oleh perantau, yakni melakukan interaksi sesama perantau yang senasib untuk mengadakan kegiatan berkumpul di rantau sambil mengenang atau membicarakan kondisi yang terjadi di kampung halaman, seperti kenangan semasa kecil, remaja, atau peristiwaperistiwa lain yang erat kaitannya dengan kampung halaman.

Suasana rindu kampung halaman yang dirasakan oleh para perantau Minangkabau merupakan dampak manusia sebagai makhluk sosial yang tidak bisa hidup tanpa bentuan atau melakukan hubungan dengan orang lain. Seorang individu atau masyarakat membutuhkan individu atau masyarakat lain, seperti teman-teman sepermainan sewaktu kecil, orang-orang terdekat atau sanak famili, dan yang paling menentukan adalah hubungan yang erat antara anak dengan ibu kandungnya.

Ditinjau dari aspek kultur atau budaya, lirik dan musik lagu Minangkabaumerupakan gambaran pemikiran atau ide pencipta lagu untuk menghadirkan suasana budaya Minangkabau dalam sebuah karya lagu. Lagu tersebut melambangkan kecintaan dan kedekatan perasaan orang Minang terhadap kampung halaman mereka yakni ranah Minang dan Rumah Gadang sebagai bentuk artifak yang melambangkan bentuk khas rumah yang sekaligus mewakili keberadaan masyarakat di Minangkabau.

Keyakinan tersebut dipegang teguh dan diperlihara oleh masyarakat Minangkabau dan memunculkan perasaan hiba serta kerinduan 
yang mendalam. Perasaan tersebut membayang di relung mata, apalagi ketika mereka tidak dapat pulang kampung atau sedang berada jauh dari kampung halaman. Perasaan tersebut melahirkan tindakan untuk segera mengenang atau mengingat peristiwa-peristiwa yang pernah dilakukan pada waktu berada di kampung halaman.

5. Aspek Pendidikan dan Nilai-nilai Edukatif

Berdasarkan paparan interpretasi hermeneutik yang dilihat dari aspek kebahasaan, musik, psikologi, dan sosiokultural terhadap lagu Minangkabau yang telah dikemukakan sebelumnya dapat ditafsirkan bahwa masyarakat Minangkabau, baik yang berada di kampung halaman maupun yang merantau ke negeri orang di seantero pelosok dunia merasakan kerinduan dan kecintaannya terhadap ranah Minangkabau apalagi Rumah Gadang yang menjadi ikon atau lambang budaya Minangkabau.

Rasa rindu dan cinta tersebut muncul karena masyarakat Minangkabau telah disuguhkan dengan adat budaya Minangkabau semenjak mereka lahir sampai menjelang ajal menjemput. Adat budaya tersebut sudah ditanamkan dan dilaksanakan di manapun mereka berada.

Nilai-nilai yang terkandung dalam lagu Minangkabaudapat diidentifikasi, sebagai berikut:
a. Cinto ranah Minang.
b. Waspada.
c. Keteguhan hati.
d. Kesatuan dan kebersamaan.
e. Musyawarah dan Mufakat.
f. Adil dan Damai.
g. Disiplin

Nilai-nilai yang telah diidentifikasi dari proses interpretasi hermeneutik secara multidisipliner terhadap lagu Minangkabau sebelumnya merupakan nilai-nilai yang sangat penting dan bermanfaat bagi pendidikan. Nilainilai tersebut memberikan tuntunan, nasehat, didikan, atau dengan kata lain nilai-nilai tersebut memiliki sifat-sifat mendidik (edukatif) generasi muda di lingkungan masyarakat Minangkabau atau peserta didik di lingkungan sekolah.

Nilai-nilai edukatif tersebut dapat dijadikan pedoman untuk mengarahkan dan mengembangkan pemahaman peserta didik terhadap nilai-nilai adat budaya mereka sendiri, yakni adat budaya Minangkabau. Nilai-nilai edukatif, seperti cinto ranah Minang, kewaspadaan, keteguhan hati, kesatuan dan kebersamaan, musyawarah danmufakat, adil dan damai, serta nilai-nilai disiplin dapat dijadikan modal bagi peserta didik untuk berinteraksi dan bersosialisasi baik di lingkungan masyarakat maupun di lingkungan sekolah dan pada akhirnya pembudayaan nilai-nilai edukatif tersebut dapat membantu membangun karakter peserta didik yang tidak terlepas dari nilai-nilai adat budaya Minangkabau.

\section{SIMPULAN}

Proses penelitian dan analisis hermeneutik secara multidisipliner terhadap Lagu Minangkabauciptaan NN (No Name) dapat mengidentifikasikan 7 (tujuh) nilai edukatif, yaitu 1) cinto ranah Minang, 2) waspada, 3) keteguhan hati, 4) kesatuan dan kebersamaan, 5) musyawarah dan mufakat, 6) adil dan damai, serta 7) disiplin. Nilai-nilai edukatif tersebut dapat dijadikan sebagai sarana untuk membangun karakter peserta didik, baik ketika berada di sekolah maupun di lingkungan keluarga atau masyarakat.

Ketujuh nilai-nilai tersebut sangat berguna bagi pelestarian nilai-nilai adat Minangkabau dan proses pengaktualisasian nilai-nilai tersebut di lingkungan sekolah dapat dijadikan sebagai sarana edukasi dalam membangun karakter peserta didik, sehingga tercapainya tujuan adat Minangkabau dan tujuan pendidikan, yakni menciptakan peserta didik yang beradat, beradab, dan berkarakter mulia.

\section{DAFTAR PUSTAKA}

Amir M.S. (2011). Adat Minangkabau: Pola hidup dan tujuan hidup orang Minang. Jakarta: Citra Harta Prima. 
Astuti, K.S. (2010, Juni 11-13). Shaping morality through music learning in formal schools in Indonesia: An evaluation study. Artikel dipublikasikan pada Asia Pasific Network for Moral Education 5th dalam Annual Conference Interdisciplinary Moral Education in Asia's Globalising Societies; Concept and Practices. Japan: Nagasaki University

Barendregt, Bart. (2002). The sound of 'longing for home': Redefining a sense of community through Minang popular music. Bijdragen tot de Taal-, Land-en Volkenkunde, 158, No: 3, 411-450: Leiden University

Darwis. (2005, November 28). Tafsir pantun Minang I. Artikel 655. Diambil pada tanggal 22 Januari 2012, dari http://www.cimbuak.net/content/view/65 $\underline{5 / 5 / 1 / 1 /}$

Djohan. (2009). Psikologi musik. Cetakan ketiga: Edisi revisi. Yogyakarta: Galang Press

Fithri, W. (2013). Mau kemana Minangkabau? Analisis hermeneutika atas perdebatan Islam dan adat Minangkabau.Yogyakarta: Gre Publishing

Fraser, J. (2011). Pop song as custom: Weddings, ethnicity, and enterpreneurs in West Sumatra. Jurnal Ethnomusicology Sping/Summer, Vol. 55, No. 2, p. 200-228. Ohio: Society for Ethnomusicology
Hajizar. (2012, Maret 13). Lagu Padang Dulu dan Kini. Artikel. Diambil pada tanggal 3 Maret 2014, dari http://albiouna.com/umum/lagu-padangdulu-dan-kini

Hakimy, I. (2004). Rangkaian mustika adat basandi syarak di Minangkabau. Bandung: Rosda Karya

Kuhl, O. (2010). Song Structure and Phenomenology: Text and Music in 'Mr. Tambourine Man'. Jurnal. Oslo: Dept. Of Musicology. Artikel. Diambil pada tanggal 22 Januari 2012, dari http://ssrn.com/abstract $=1532795$ Universit $\mathrm{y}$ of Oslo

Merriam, A.P. (1964). The anthropology of music. Evanston, Illionis: Northwestern University Press

Muhadjir, N. (2003). Ilmu pendidikan dan perubahan sosial: Teori pendidikan pelaku sosial kreatif. Yogyakarta. Raka Sarasin

Zainuddin, M. (2010). Pelestarian dan eksistensi dinamis adat Minangkabau. Yogyakarta: Ombak

Zulfadli. (t.t). Lirik lagu Minang lamo. Diambil pada tanggal 22 Januari 2012, dari http://laguminanglamo.wordpress.com 